\title{
Submarine glacial landforms on the Bay of Fundy-northern Gulf of Maine continental shelf
}

\author{
B. J. TODD ${ }^{1 *}$, J. SHAW ${ }^{1} \&$ P. C. VALENTINE ${ }^{2}$ \\ ${ }^{1}$ Geological Survey of Canada, Natural Resources Canada, P.O. Box 1006, Dartmouth, Nova Scotia, Canada B2Y \\ $4 A 2$ \\ ${ }^{2}$ US Geological Survey, 384 Woods Hole Road, Woods Hole, Massachusetts, USA 02543 \\ *Corresponding author (e-mail:Brian.Todd@canada.ca)
}

The Bay of Fundy-northern Gulf of Maine region surrounds the southern part of Nova Scotia, encompassing, from west to east, the Bay of Fundy, Grand Manan Basin, German Bank, Browns Bank, Northeast Channel, and northeastern Georges Bank (Fig. 1a). During the last glacial maximum ( $24-20{ }^{14} \mathrm{C}$ ka BP), the southeast margin of the Laurentide Ice Sheet (LIS) occupied the study area, the rest of the Gulf of Maine, and the continental Scotian Shelf off Atlantic Canada (see Dyke et al. 2002, Fig. 1; Hundert \& Piper 2008, Fig. 16; Shaw et al. 2006, Fig. 8). Early mapping of the glaciated region on the Scotian Shelf using side-scan sonar imagery and seismic reflection profiles revealed topographic features interpreted to be recessional moraines indicative of retreat of the LIS (King et al. 1972; King 1996; Stea et al. 1998). Subsequently, multibeam sonar seafloor mapping of local-scale glacial landforms on the inner Scotian Shelf off Halifax, Nova Scotia (Fig. 1a) provided further information on the dynamics of the advance and retreat of the ice sheet (Loncarevic et al. 1994). Interpretation of seismic reflection profiles across Georges Bank revealed that the surficial sediment is a veneer of glacial debris transported to Georges Bank by the LIS during the late Pleistocene from continental areas to the north (Shepard et al. 1934; Knott \& Hoskins 1968; Oldale \& Uchupi 1970; Schlee 1973; Schlee \& Pratt 1970; Twichell et al. 1987; Fader et al. 1988). Recent high-resolution multibeam sonar surveys of German Bank and the Bay of Fundy mapped a complex of ice-advance and ice-retreat features attributed to the activity of the LIS (Todd et al. 2007; Todd \& Shaw 2012).

Fast-flowing marine ice streams exhibit a suite of glacial geomorphologic features diagnostic of ice advance (Dowdeswell et al. 2007, 2008, 2010), and the mapping of these and ice-retreat features enables the reconstruction of the spatial pattern of ice movement (Ottesen et al. 2005). In a conceptual model of ice sheet dynamics in Atlantic Canada, Shaw et al. (2006) indicate that multiple flow lines within the LIS converge in the Bay of Fundy, indicating that an ice stream 
may have occupied the bay. Recent studies in the Bay of Fundy-northern Gulf of Maine region provide evidence that a large ice stream flowed out of the Bay of Fundy and occupied the shelf region south of Nova Scotia (Todd \& Shaw 2012).

We illustrate and describe the geomorphology of the major subglacial, ice-marginal and glacimarine landforms in the study area in order to refine our knowledge of the glacial and deglacial history of the southeastern marine margin of the LIS. We focus chiefly on glacial and deglacial features in areas directly affected by ice flow into the northern Gulf of Maine through the Bay of Fundy, including the bay itself, Grand Manan Basin, German Bank, and Northeast Channel (Fig. 1a). Glacial geomorphology is revealed in high-resolution multibeam sonar imagery set within regional-scale bathymetric data (Olex, 2015), the latter produced from multiple single-beam echo-sounder profiles. High-resolution seismic profiles show the crosssectional structure of glacial features.

\section{Description of shelf landforms}

\section{Bay of Fundy Region}

The seafloor over most of central Bay of Fundy (Fig. 1a) is dominated by multiple, sub-parallel ridges, in places demonstrating pronounced convexity to the southwest (Fig. 2a, b). The ridges are confined to the central section of the Bay of Fundy and do not extend to nearshore regions of outcropping bedrock. Two size classes are evident: smaller ridges (2-8 m high, 300-400 m wide) which are numerous and widespread, and larger and wider ridges (up to 15 m high, 800-1000 m wide) which are less common.

Grand Manan Basin is the deep easternmost entrance to the Bay of Fundy where water depths reach $230 \mathrm{~m}$ (Fig. 1a). The basin forms a roughly parallel-sided, southwest-northeast oriented channel 20 to $25 \mathrm{~km}$ wide, with water depths shallowing to $160 \mathrm{~m}$ where the basin opens to the Gulf of Maine (Fig. 2d). On the floor of Grand Manan Basin are two prominent streamlined landforms rising 50 to $70 \mathrm{~m}$ above the surrounding seabed (Fig. 2d). The northeast feature exhibits a $4 \mathrm{~km}$-broad, steep slope facing northeast, while the southwest mound is approximately $800 \mathrm{~m}$ wide and displays a steep, pointed termination also facing northeast (Fig. 2 e). Both features flatten and widen to the southwest over a distance of 4 to $7 \mathrm{~km}$. The major axes of these streamlined features parallel the axis of Grand Manan Basin. 
Much of the seabed in Grand Manan Basin is incised with a pattern of linear to curvilinear depressions or grooves generally aligned southwest-northeast and often cross-cutting (Fig. 2d, e, g). These features demonstrate a range of size, but many of the better-defined grooves have widths of 100-150 m, depths of 3-4 m and display berms $<1 \mathrm{~m}$ in height. Some of grooves can be traced in length up to $10 \mathrm{~km}$. The cross-cutting nature of these features implies an older relative age for the groove segment that has been disturbed (Fig. 2e).Irregularly-shaped, subcircular depressions up to $150 \mathrm{~m}$ in width and $6 \mathrm{~m}$ in depth also occur on the tops of the streamlined features (Fig. 2e) and are very common along the northern flank of the Grand Manan Basin in water depths of $\sim 80$ to $170 \mathrm{~m}$ (Fig. 2d). Isolated larger depressions, up to $250 \mathrm{~m}$ in width and $10 \mathrm{~m}$ in depth occur in the deepest portion of the basin.

On the southern flank of Grand Manan Basin, an elongated, topographically rugged ridge of exposed bedrock (upper part of Fig. 2f) has a fractured appearance, and its surface is incised with southwest-northeast striking narrow grooves, some reaching $1000 \mathrm{~m}$ in length. They exhibit a width to depth ratio of approximately 6 to 10 . The presence of a number of exposed circular feeder dykes (not visible in Fig. 2f) indicates that the bedrock is basalt (Wade et al. 1996). Attached to the eastern margin of the bedrock ridge are similarly-aligned, elongated sediment mounds, up to $9 \mathrm{~m}$ in height, with lengths up to $1200 \mathrm{~m}$ and widths of approximately $100 \mathrm{~m}$ and an elongation (length to width) ratio of 12 (Fig. 2f). Elongated mounds of like appearance are aligned north-south on the opposite flank of Grand Manan Basin, northeast of Northeast Bank (Fig. 2d).

To the east of the bedrock ridge, in water depths of 70-110 m, is a field of somewhat shorter mounds (lower part of Fig. 2f) that extends southwestward for $40 \mathrm{~km}$ (Fig. 2d). The long axes of these mounds are oriented southwest-northeast. The mounds rise 11-20 m above the seafloor and are typically 900-2000 $\mathrm{m}$ in length and 300-700 $\mathrm{m}$ in width with an elongation ratio of 3 .

\section{Northern Gulf of Maine}

There is little multibeam imagery of the seabed in the northern Gulf of Maine. Seafloor features are identified using seismic reflection profiles and a compilation of single-beam echo-sounder profiles. Seafloor physiography is expressed in a series of basins and intervening ridges (Fig. 1a, b). Grand Manan Basin is separated from Jordan Basin by Grand Manan Banks; Jordan Basin is 
separated from Crowell Basin by Truxton Swell; and Crowell Basin is separated from Georges Basin by Sewell Ridge. The ridges and basin flanks are heavily incised with linear and curvilinear grooves shown as hummocky seabed in subbottom profiles (see Truxton Swell and Georges Basin insets in Figs. 1b, c).

\section{German Bank}

Parallel ridges spaced 150-200 m apart occur in profusion on the seabed of German Bank (Figs. 1a, 3a). The ridges vary in height and width. Small ridges are approximately $1.5 \mathrm{~m}$ high and 40 m wide. Large ridges are 5 to $8 \mathrm{~m}$ high and 100 to $130 \mathrm{~m}$ wide (labelled A, B, C in Fig. 3a, b). Most ridges are symmetrical in cross-section, with some of the larger ridges displaying asymmetry with a gentle slope to the north and a steeper slope to the south. The strike of the ridge crests is generally west-southwest-east-northeast. Individual ridge crests can be traced horizontally from $2 \mathrm{~km}$ up to almost $10 \mathrm{~km}$ in length. Most ridge crests are simple lines in planform, but in some areas the crests are complex with bifurcating crest lines and short, en echelon crest segments. The large ridge crests are formed of multiple curved sections 2 to $5 \mathrm{~km}$ in length with the crests convex toward the southeast. Individual ridges traverse bathymetric ranges of up to $25 \mathrm{~m}$ along strike. Cobbles and boulders were observed and recovered from ridge crests. The seabed in troughs between ridges is smooth-surfaced, as observed in multibeam imagery, and the seabed is composed of sand and pebble gravel.

\section{Browns Bank}

The northern margin of Browns Bank is marked by a prominent curvilinear ridge (FM on Fig. 1a). that extends westward to deep water in Georges Basin (SR on Fig. 1a). This feature can be traced approximately $280 \mathrm{~km}$ from Georges Basin in the west to Roseway Basin in the east and occurs in water depths ranging from $250 \mathrm{~m}$ in Georges Basin to $30 \mathrm{~m}$ on Browns Bank. In places the ridge rises 18 to $20 \mathrm{~m}$ above the level of the surrounding seabed and exhibits basal widths of $\sim 800 \mathrm{~m}$. The shallowest portion of the ridge has a flat-topped area approximately $100 \mathrm{~m}$ wide. On southern Browns Bank adjacent to Northeast Channel, a small field of relatively short, straight parallel ridges is faintly discernible in the multibeam imagery (Fig. 3d). The largest ridges attain heights of 1 to $3 \mathrm{~m}$ and widths of 60 to $80 \mathrm{~m}$. The ridge crests strike westsouthwest-north-northeast with the longest ridge crest being about $1500 \mathrm{~m}$ in length. 
Northeast Channel

The seabed within Northeast Channel (Fig. 1a) hosts numerous irregular, subcircular or ovalshaped depressions or pits exhibiting a range of sizes (Fig. 3d). Small pits (100-200 m wide, 5-7 m deep) are found in water depths from 220 to $300 \mathrm{~m}$. Large pits with dimensions 300 to $400 \mathrm{~m}$ across and up to $30 \mathrm{~m}$ deep occur in water depths of 300 to 400 m near the mouth of Northeast Channel. At greater depths, the multibeam sonar system was unable to clearly image features of this size. Associated with the oval pits, at water depths greater than $220 \mathrm{~m}$, much of the seabed in Northeast Channel is incised with linear and curvilinear grooves. As noted previously for similar

features in Grand Manan Basin, these curvilinear grooves demonstrate a range of sizes, but many are on the order of $2 \mathrm{~m}$ deep and 60 to $80 \mathrm{~m}$ wide; one notable groove can be traced for $14 \mathrm{~km}$ over a water depth range of $22 \mathrm{~m}$ (Fig. 3d, e). Along its length, this groove is roughly $150 \mathrm{~m}$ wide, $8 \mathrm{~m}$ deep, with flanking berms of 3 to $5 \mathrm{~m}$ in height. These curvilinear features display a cross-cutting nature similar to that observed in Grand Manan Basin; here curvilinear grooves with a muted topographic expression are cross-cut by grooves with well-defined edges.

\section{Georges Bank}

A field of low parallel ridges that strike north-south is present on northern Georges Bank (Figs. 1a, 3c). Their topographic expression is subtle, with heights less than one metre and variable spacing from 10 to $100 \mathrm{~m}$. Individual crests can be traced horizontally from $200 \mathrm{~m}$ to $2 \mathrm{~km}$, and the longer ridges are gently convex to the east. The ridges are overlain in places by mobile sediment bedforms up to $5 \mathrm{~m}$ high.

\section{Interpretation of shelf landforms}

\section{Bay of Fundy Region}

Interpretation of seismic reflection profiles in the central Bay of Fundy indicates that the ridges in the Bay of Fundy are composed of acoustically incoherent ice-contact sediment overlying glacimarine sediment and bedrock (Fig. 2c).The ice-contact sediment reaches over $20 \mathrm{~m}$ in thickness in the small ridges and over $50 \mathrm{~m}$ in thickness in the large ridges. Both the bedrock and the glacimarine sediments are separated by an angular unconformity from overlying ice-contact sediment (Fig. 2c). The upper surfaces of the bedrock and the glacimarine sediments are 
smoothly undulating. Bedrock undulations have wavelengths of kilometers and heights of less than $10 \mathrm{~m}$. Glacimarine sediment undulations have wavelengths of 1 to $2 \mathrm{~km}$, and reach heights of almost $20 \mathrm{~m}$ in places. Based on their geomorphology and seismostratigraphic character, the lobe-shaped ridges with pronounced southwest-trending convexity in the Bay of Fundy (Fig. 2a, b) are interpreted as recessional moraines marking sequential positions of the complex planform of the Laurentide Ice Sheet terminus as it retreated northeast into the bay during the last deglaciation (Todd \& Shaw 2012. During regional ice sheet retreat, continual local advances and retreats resulted in older moraines being overprinted by younger moraines, giving a nested appearance to the moraine crests. This is illustrated along a seismostratigraphic section in Grand Manan Basin (Fig. 2c) where slightly undulating bedrock is interpreted as evidence of bedrock erosion by ice sheet advance, which was followed by sea level rise and deposition of glacimarine sediment. In turn, these sediments were eroded by an ice sheet advance that imparted to them an undulating surface. Later, this surface was covered with ice-contact sediment deposited from a series of recessional moraines that exhibit many well-formed crests.

Within Grand Manan Basin, there is evidence of a subglacial landsystem in the form of channelized ice flowing from northeast to southwest. The large grooves in bedrock (upper part of Fig. 2f) are similar in morphology and width to depth ratio (6 to 10) to megagrooves mapped both onshore and offshore in northwest Scotland by Bradwell et al. (2007, 2008). These authors describe megagrooves as linear, erosional features with negative topographic expression formed by fast ice flow within an ice sheet grounded on bedrock. The elongated mounds located south of the bedrock knolls are streamlined from northeast to southwest (parallel to the basin axis) and interpreted as megaflutes composed of till shaped by flowing ice. In some places megafluted sediment tails are located in the lee of the bedrock features (Fig. 2f). The relatively short mounds lying to the east of the bedrock (lower part of Fig. 2f) and whose long axes also parallel the basin axis are interpreted as drumlins, also composed of till (Menzies 1979; Clark et al. 2009). Seismic reflection profiles (not shown here) reveal that the mounds are constructed of acoustically incoherent deposits, interpreted as ice-contact sediment, similar to sediment flooring Grand Manan Basin (Fig. 2g).The distinction between drumlins and megaflutes is based on the elongation (length to width) ratio of the bedform (Rose 1987), and drumlins grade into megaflutes as the elongation ratio increases. The typical elongation ratio for drumlins south of the bedrock ridge is approximately 3, whereas the more elongated features have an elongation 
ratio of 12, diagnostic of megaflutes.

Linear to curvilinear seafloor grooves in glaciated terrain have been interpreted as the signature of the ploughing action of the keels of sea-ice floes or icebergs impinging on the sedimentary seafloor (e.g., Todd et al. 1988; Woodworth-Lynas et al. 1991; Héquette et al. 1995). Much of the seafloor of the central and outer Bay of Fundy and Grand Manan Basin shows evidence of iceberg ploughing (Fig. 2c, d, e, g). In Grand Manan Basin, the ploughmarks demonstrate a preferred orientation parallel to the basin axis. The subcircular pits associated with the ploughmarks are interpreted as being caused by bobbing or semi-grounded icebergs (Dowdeswell et al. 1993) or by grounded icebergs rotating and impacting the seabed as they melt (Syvitski et al. 1996). See Todd \& Shaw (2012) for a detailed description and interpretation of glacial landforms in the Bay of Fundy and Grand Manan Basin regions.

\section{Northern Gulf of Maine}

The deep basins in the northern Gulf of Maine that extend from the Bay of Fundy to Georges Basin are separated by three prominent ridges (Grand Manan Banks, Truxton Swell, Sewell Ridge) that are interpreted to represent recessional moraines formed during the retreat of the Laurentide Ice Sheet (Fig. 1a). Sewell Ridge, which separates Crowell Basin from Georges Basin, extends eastward into shallower water where it becomes Fundian Moraine, a part of the Scotian Shelf moraine complex. The northern Gulf of Maine seabed shows evidence of ploughing by icebergs on bathymetric highs such as Truxton Swell (Fig. 1b). The southern flank of Georges Basin is particularly heavily incised with ploughmarks aligned parallel to the banks' northern flank and to the axis of the basin and Northeast Channel (Fig. 1c). Considered collectively, the ploughmarks in the Bay of Fundy-northern Gulf of Maine region are interpreted as evidence of a persistent and high volume flux of icebergs drifting eastward in the Gulf of Maine and out through Northeast Channel to the North Atlantic Ocean during deglaciation of the Laurentide Ice Sheet.

\section{German Bank}

Based on their geomorphology, the parallel ridges on German Bank are interpreted to be De Geer moraines (Todd et al. 2007). These features characteristically are oriented transverse to the direction of ice flow and are formed at, or close to, the grounding lines of water-terminating 
glaciers (De Geer 1889, 1940; Sollid 1989; Larsen et al. 1991; Aartolahti et al. 1995; Blake 2000; Lindén \& Möller 2005). De Geer moraines have been recognized and mapped north of the Bay of Fundy in Maine and New Brunswick (Borns et al. 1987). Swarms of similar small transverse ridges have been observed on the seafloor beyond retreating tidewater glaciers in Svalbard (Whittington et al. 1997). Ottesen \& Dowdeswell (2006) demonstrated that, based on interpretation of multibeam sonar imagery and historical aerial photographs, these ridges are small push moraines that are produced annually when a tidewater glacier terminus undergoes minor re-advance each winter during more general retreat.

\section{Browns Bank}

The large, prominent, linear ridge along the northern margin of Browns Bank was mapped as part of the Fundian Moraine by King (1969) and Todd et al. (1999) (Fig. 1a). This feature extends westward into deeper water where is forms Sewell Ridge, separating northern Georges Basin from Crowell Basin (Fig. 1a, c). Sidescan sonograms from previous studies show that Sewell Ridge is covered with large relict iceberg ploughmarks, that the moraine is regionally hummocky with multiple broad ridges, and that pockets of glacimarine sediment occur in depressions on its surface (King \& Fader 1986). The Fundian Moraine extends eastward to bisect Roseway Basin (Fig. 1a). On the southwestern corner of Browns Bank adjacent to Northeast Channel, the small field of parallel ridges adjacent to Northeast Channel is interpreted to be De Geer moraines (Figs. 1a, 3d).

\section{Northeast Channel}

Seafloor grooves and pits in Northeast Channel are similar to the features observed in the Bay of Fundy and the northern Gulf of Maine. They are interpreted to have resulted from the ploughing action of the keels of icebergs impinging on seafloor sediment. Some of the larger ploughmarks terminate in pits at their northwestern ends. Iceberg ploughmarks extend northwestward into water depths of approximately $200 \mathrm{~m}$ (Fig. 2d). The ploughmark morphology and distribution pattern suggest that during the last part of the deglacial period, icebergs were transported toward the Gulf of Maine from the Atlantic Ocean but that their deep draft limited their intrusion into the eastern part of Northeast Channel.

\section{Georges Bank}


The low parallel ridges mapped on Georges Bank are interpreted to be De Geer moraines (Fig. 3c). The features shown in the multibeam image are the first physiographic evidence that early interpretations of the extent of glacial advance onto this part of Georges Bank, which were based only on the distribution of gravel and coarse sand, are correct (Schlee 1973; Schlee \& Pratt 1970).

\section{Discussion: landform distribution and schematic model}

The mapping of the distribution of moraines on the Scotian Shelf by early surveys provided a basis for developing a general interpretation of the advance and retreat of the Laurentide Ice Sheet during the last glacial maximum. The Scotian Shelf end moraine complex (Fig. 4) is a series of coast-parallel recessional moraines interpreted to have formed at grounding points of a floating-front ice margin during late Wisconsinan ice retreat across the shelf (King et al. 1972; King \& Fader 1986; King 1996; Stea et al. 1998). These moraines are variably buried and exposed across the Scotian Shelf, and some extend up to $75 \mathrm{~m}$ in height, well above the surrounding terrain. By seismostratigraphically correlating dated sediment sequences in the shelf basins to moraine formation, King (1996) refined the depositional pattern for the moraine complex, suggesting that it represented time-transgressive deposition by shoreward (i.e., northwestward) retreating glaciers arranged in an en échelon pattern with a general northeasterly trend.

More recent seafloor mapping efforts, using high-resolution multibeam technology, have focused on documenting the distribution of glacial and deglacial features on the western and southern margins of Nova Scotia, from the Bay of Fundy in the west to Browns Bank and the Northeast Channel in the east (Fig. 4). Drumlins, megaflutes, megagrooves and crag-and-tails are streamlined features that serve as directional indicators of ice advance. Recessional moraines delineate the extent of glacial advance and episodic retreat. De Geer moraines map the episodic retreat of water-terminating glacial ice. Iceberg ploughmarks and pits are typical of deglacial conditions during which bergs calve from ice shelves and water-terminating glaciers.

The geomorphology of Grand Manan Basin, and the pattern of major axes of subglacial landforms on its flanks, suggests it hosted topographically-controlled, channelized ice of the Laurentide Ice Sheet flowing from northeast to southwest from the Bay of Fundy to the northern 
Gulf of Maine, German Bank and Browns Bank (Fig. 4a). The presence of similar streamlined subglacial bedforms in the form of mega-scale glacial lineations has been used to infer the presence of fast-flowing glacial ice streams on the continental shelves of both the Arctic (Ottesen et al. 2005, 2007; Ottesen \& Dowdeswell, 2009; Dowdeswell et al. 2010) and the Antarctic (Dowdeswell et al. 2004). While the Bay of Fundy megaflutes are smaller than those, they resemble in size megaflutes formed by an ice advance 100 yr BP mapped off Svalbard by Ottesen \& Dowdeswell (2006). The distribution and orientation of drumlins on the shelf off southwestern Nova Scotia and on German Bank is further evidence of ice advance from the Bay of Fundy region (Fig. 4).

After the glacial maximum, the Laurentide Ice Sheet front retreated northward ( 18-15 ka) forming moraines on the Scotian Shelf, Browns Bank and German Bank (Fig. 4a). In the Gulf of Maine, the retreat of the ice margin was marked by the breakup of floating ice shelves (Schnitker et al. 2001) which became a source of the icebergs that ploughed and pitted the flanks of banks and the floors of shallow basins. During the retreat of the outer part of the ice sheet, the Bay of Fundy ice stream continued to create elongated landforms within Grand Manan Basin and along its southern flank, incising megagrooves into outcropping bedrock and forming sediment into megaflutes below relatively fast flowing ice. Later ( $15-10 \mathrm{ka})$, as the retreat of the Laurentide Ice Sheet progressed, the calving ice front of the Fundy ice stream retreated episodically northeastward up the bay, leaving a nested pattern of recessional moraines on the central bay floor (Fig. 4). Details of the chronologic control on the retreat process in the Bay of Fundy are given in Todd \& Shaw (2012).

\section{References}

AARTOLAHTI, T., KOIVISTO, M. \& NENONEN, K. 1995. De Geer moraines in Finland. Geological Survey of Finland Special Paper 20, 67-74.

BLAKE, K.P. 2000. Common origin for De Geer moraines of variable composition in Raudvassdalen, northern Norway. Journal of Quaternary Science, 15, 633-644.

BORNS, H.W., Jr., GADD, N.R. et al. 1987. Quaternary geologic map of the Quebec $4^{\circ}$ by $6^{\circ}$ quadrangle, United States and Canada. In: Quaternary Geologic Atlas of the United States. United States Geological Survey Miscellaneous Investigations Series Map I-1420 (NL-19), scale 1:1 000000 . 
BRADWELL, T., STOKER, M.S. \& LARTER, R.D. 2007. Geomorphological signature and flow dynamics of The Minch palaeo-ice stream, NW Scotland. Journal of Quaternary Science, 22, 609-617.

BRADWELL, T., STOKER, M. \& KRABBENDAM, M. 2008. Megagrooves and streamlined bedrock in NW Scotland: The role of ice streams in landscape evolution. Geomorphology, 97, 135-156.

CLARK, C.D., HUGHES, A.L.C., GREENWOOD, S.L., SPAGNOLO, M. \& NG, F.S.L. 2009. Size and shape characteristics of drumlins, derived from a large sample, and associated scaling laws. Quaternary Science Reviews, 28, 677-692.

DE GEER, G.F. 1889. Ändmoräner I trakten mellan Spånga och Sundbyberg. Geologiska Föreningens i Stockholm Förhandlingar, 11, 395-397.

DE GEER, G.F. 1940. Geochronologia Suecica Principles. Kungliga Svenska Vetenskapsakademiens Handlingar, Ser. III, 18, 367 p.

DOWDESWELL, J.A., VILLINGER, H., WHITTINGTON, R.J. \& MARIENFELD, P. 1993. Iceberg scouring in Scoresby Sund and on the East Greenland Continental Shelf. Marine Geology, 111, 37-53.

DOWDESWELL, J.A., Ó COFAIGH, C. \& PUDSEY, C.J. 2004. Continental slope morphology and sedimentary processes at the mouth of an Antarctic palaeo-ice stream. Marine Geology, 204, 203-214.

DOWDESWELL, J.A., OTTESEN, D., RISE, L. \& CRAIG, J. 2007. Identification and preservation of landforms diagnostic of past ice-sheet activity on continental shelves from three-dimensional seismic evidence. Geology, 35, 359-362.

DOWDESWELL, J.A., OTTESEN, D., EVANS, J., Ó COFAIGH, C. \& ANDERSON, J.B. 2008. Submarine glacial landforms and rates of ice-stream collapse. Geology, 36, 819-822.

DOWDESWELL, J.A., HOGAN, K.A., EVANS, J., NOORMETS, R., Ó COFAIGH, C. \& OTTESEN, D. 2010. Past ice-sheet flow east of Svalbard inferred from streamline subglacial landforms. Geology, 38, 163-166.

DYKE, A.S., ANDREWS, J.T. et al. 2002. The Laurentide and Innuitian ice sheets during the Last Glacial Maximum. Quaternary Science Reviews, 21, 9-31.

FADER, G.B.J., KING, E., GILLESPIE, R. \& KING, L.H. 1988. Surficial geology of Georges Bank, Browns Bank, and the southeastern Gulf of Maine. Geological Survey of Canada Open 
File 1692, 3 sheets, scale 1:300 000.

HÉQUETTE, A., DESROSIERS, M. \& BARNES, P.W. 1995. Sea ice scouring on the inner shelf of the southeastern Canadian Beaufort Sea. Marine Geology, 128, 201-219.

HUNDERT, T. \& PIPER, D.J.W. 2008. Late Quaternary sedimentation on the south-western Scotian Slope, eastern Canada: relationship to glaciation. Canadian Journal of Earth Sciences, 45, 267-285.

KING, L.H. 1969. Submarine end moraines and associated deposits on the Scotian Shelf. Geological Society of America Bulletin, 80, 83-96.

KING, L.H. 1996. Late Wisconsinan ice retreat from the Scotian Shelf. Geological Society of America Bulletin, 108, 1056-1067.

KING, L.H. \& FADER, G.B.J. 1986. Wisconsinan glaciation of the continental shelf of southeast Atlantic Canada. Geological Survey of Canada Bulletin 363, 72 p.

KING, L.H., MACLEAN, B. \& DRAPEAU, G. 1972. The Scotian Shelf submarine end-moraine complex. In: Gill, J.E. (ed.) Section 8, Marine Geology and Geophysics. 24th session, International Geological Congress, Montreal, Québec, 237-249.

KNOTT, S.T. \& HOSKINS, H. 1968. Evidence of Pleistocene events in the structure of the continental shelf off the northeastern United States. Marine Geology, 6, 5-43.

LARSEN, E., LONGVA, O. \& FOLLESTAD, B.A. 1991. Formation of De Geer moraines and implications for deglaciation dynamics. Journal of Quaternary Science, 6, 263-277.

LINDÉN, M. \& MÖLLER, P. 2005. Marginal formation of De Geer moraines and their implication on the dynamics of grounding-line recession. Journal of Quaternary Science, 20, 113-133.

LONCAREVIC, B.D., COURTNEY, R.C. et al. 1994. Sonography of a glaciated continental shelf. Geology, 22, 747-750.

MENZIES, J. 1979. A review of the literature on the formation and location of drumlins. Earth Science Reviews, 14, 315-359.

OLDALE, R.N. \& UCHUPI, E. 1970. The glaciated shelf off northeastern United States. United States Geological Survey Professional Paper 700B, B167-B173.

OLEX automatic seabed charting. 2015. http://www.olex.no/index_e.html (accessed January 22, 2015).

OTTESEN, D. \& DOWDESWELL, J.A. 2006. Assemblages of submarine landforms produced by tidewater glaciers in Svalbard. Journal of Geophysical Research, 111 (F01016), 16 p., doi: 
10.1029/2005JF000330.

OTTESEN, D. \& DOWDESWELL, J.A. 2009. An inter-ice-stream glaciated margin: Submarine landforms and a geomorphic model based on marine-geophysical data from Svalbard. Geological Society of America Bulletin, 121, 1647-1665.

OTTESEN, D., DOWDESWELL, J.A. \& RISE, L. 2005. Submarine landforms and the reconstruction of fast-flowing ice streams within a large Quaternary ice sheet: The 2500-kmlong Norwegian-Svalbard margin $\left(57^{\circ}-80^{\circ} \mathrm{N}\right)$. Geological Society of America Bulletin, 117, 1033-1050.

OTTESEN, D., DOWDESWELL, J.A., LANDVIK, J. \& MIENERT, J. 2007. Dynamics and retreat of the Late Weichselian ice sheet on Svalbard inferred from high-resolution sea-floor morphology. Boreas, 36, 286-306.

ROSE, J., 1987. Drumlins as part of a glacier bedform continuum. In: Menzies, J. \& Rose, J. (eds) Drumlin Symposium. Balkema, Rotterdam, 103-116.

SCHNITKER, D., BELKNAP, D.F., BACCHUS, T.S., FRIEZ, J.K., LUSARDI, B.A. \& POPEK, D.M. 2001. Deglaciation of the Gulf of Maine. In: Weddle, T.K. \& Retelle, M.J. (eds) Deglacial history and relative sea-level changes, northern New England and adjacent Canada. Geological Society of America Special Paper 351, Boulder, Colorado, 9-34.

SCHLEE, J. 1973. Atlantic continental shelf and slope of the United States- sediment texture of the northeastern part. United States Geological Survey Professional Paper 529-L, 64 p.

SCHLEE, J. \& PRATT, R.M. 1970. Atlantic continental shelf and slope of the United States-gravels of the northeastern part. United States Geological Survey Professional Paper 529-H, 39 p.

SHAW, J., STEA, R.R. et al. 2006. A conceptual model of the deglaciation of Atlantic Canada. Quaternary Science Reviews, 25, 2059-2081.

SHEPARD, F.P., TREFETHEN, J.M. \& COHEE, G.V. 1934. Origin of Georges Bank. Geological Society of America Bulletin, 45, 281-302.

SOLLID, J.L. 1989. Comments on the genesis of De Geer moraines. Norsk Geografisk Tidsskrift, 43, 45-47.

STEA, R.R., PIPER, D.J.W., FADER, G.B.J. \& BOYD, R. 1998. Wisconsinan glacial and sea-level history of Maritime Canada, a correlation of land and sea events. Geological Society of America Bulletin, 110, 821-845.

SYVITSKI, J.P.M., LEWIS, C.F.M. \& PIPER, D.J.W. 1996. Palaeoceanographic information 
derived from acoustic surveys of glaciated continental margins: examples from eastern Canada. In: Andrews, J.T., Austin, W.E.N., Bergsten, H. \& Jennings, A.E. (eds) Late Quaternary Paleoceanography of the North Atlantic Margins. Geological Society Publication No. 111, 5176.

TODD, B.J. \& SHAW, J. 2012. Laurentide Ice Sheet dynamics in the Bay of Fundy, Canada, revealed through multibeam sonar mapping of glacial landsystems. Quaternary Science Reviews, 58, 83-103.

TODD, B.J., FADER, G.B., COURTNEY, R.C. \& PICKRILL, R.A. 1999. Quaternary geology and surficial sediment processes, Browns Bank, Scotian Shelf, based on multibeam bathymetry. Marine Geology, 162, 165-214.

TODD, B.J., VALENTINE, P.C. \& SHAW, J. 2013. Shaded seafloor relief, Georges Bank, Fundian Channel, and Northeast Channel; Sheet 5, Gulf of Maine. Geological Survey of Canada, Map 2195A, scale 1:50 0000.

TODD, B.J., LEWIS, C.F.M. \& RYALL, P.J.C. 1988. Comparison of trends of iceberg scour marks with iceberg trajectories and evidence of paleocurrent trends on Saglek Bank, northern Labrador Shelf. Canadian Journal of Earth Sciences, 25, 1374-1383.

TODD, B.J., VALENTINE, P.C., LONGVA, O. \& SHAW, J. 2007. Glacial landforms on German Bank, Scotian Shelf: evidence for Late Wisconsinan ice-sheet dynamics and implications for the formation of De Geer moraines. Boreas, 36, 148-169.

TWICHELL, D.C., BUTMAN, B. \& LEWIS, R.S. 1987. Shallow structure, surficial geology, and the processes currently shaping the bank. In: Backus, R.H. (ed.) Georges Bank. Massachusetts Institute of Technology Press, Cambridge, Massachusetts, 32-37.

WADE, J.A., BROWN, D.E., TRAVERSE, A. \& FENSOME, R.A. 1996. The Triassic-Jurassic Fundy basin, eastern Canada: regional setting, stratigraphy and hydrocarbon potential. Atlantic Geology, 32, 189-231.

WHITTINGTON, R.J., FORSBERG, C.F. \& DOWDESWELL, J.A. 1997. Seismic and side-scan sonar investigations of recent sedimentation in an ice-proximal glacimarine setting, Kongsfjorden, north-west Spitsbergen. In: Davies, T.A., Bell, T. et al. (eds) Glaciated Continental Margins: An Atlas of Acoustic Images. Chapman and Hall, London, 175-178. WOODWORTH-LYNAS, C.M.T., JOSENHANS, H.W., BARRIE, J.V., LEWIS, C.F.M. \& PARROTT, D.R. 1991. The physical processes of seabed disturbance during iceberg grounding 
and scouring. Continental Shelf Research, 11, 939-961.

Any use of trade, product, or firm names is for descriptive purposes only and does not imply endorsement by the U.S. Government.

Fig. 1. Regional topography and seafloor features of the Bay of Fundy-northern Gulf of Maine shelf system. Location shown as a red box on the inset map of the western Atlantic Ocean. (a) Single-beam-bathymetry of the Bay of Fundy-northern Gulf of Maine system. Acquisition system Olex (2015). Grid-cell size $\sim 45 \mathrm{~m}$. Adjacent regional bathymetry and landmass topography from GEBCO_08. GMB is Grand Manan Basin; GMBk is Grand Manan Banks; JB is Jordan Basin; TS is Truxton Swell; GBM is German Bank Moraines; SR is Sewell Ridge; FM is Fundian Moraine. (b) 207-km long seismic reflection profile $\mathrm{x}-\mathrm{x}^{\prime}$ showing Grand Manan Basin, Grand Manan Banks, Jordan Basin and Truxton Swell. IC is ice-contact sediment; BR is bedrock. Acquisition system 6 cubic inch HGS sleeve gun and single channel NSRF hydrophone streamer. Frequency 160-2000 Hz. VE x 275. Inset of Truxton Swell shows iceberg ploughmarks in seabed. Acquisition system ORE $3.5 \mathrm{kHz}$ profiler. VE x 37. (c) 92-km long seismic reflection profile $y-y^{\prime}$ showing Crowell Basin, Sewell Ridge, Georges Basin (white arrows show where erosion has truncated pre-existing reflectors) and Georges Bank. IC1 and IC2 are ice-contact sediment; BR is bedrock. Acquisition system 10 cubic inch sleeve gun and 100 foot, single channel GF30 hydrophone streamer. Frequency 200-750 Hz. VE x 55. Inset of southern flank of Georges Basin shows iceberg ploughmarks in seabed Acquisition system Huntec Deep-Tow Seismic. Frequency 0.5-8 kHz. VE x 29.

Fig. 2. Seafloor bathymetric imagery and seismic reflection cross-sections showing glacial features in the Bay of Fundy. See Fig. 1a for locations of images. (a) Multibeam-bathymetric image of central Bay of Fundy showing the curving pattern of recessional moraines. (b) Enlarged image of recessional moraines showing lobate character and overprinting from southwest to northeast. (c) 5.5-km long seismic reflection profile across a number of arcuate recessional moraines. The surfaces of the moraine ridges display iceberg ploughmarks. IC2 is ice-contact sediment whose surface at the seabed displays recessional moraines and iceberg ploughmarks. GM is glacimarine sediment; BR is bedrock: AU is angular inconformity. Acquisition system 
Huntec Deep-Tow Seismic. Frequency 0.5-8 kHz. VE x 33. (d) Multibeam-bathymetric image showing the glaciated trough and related glacial features of Grand Manan Basin. NEB is Northeast Bank. (e) Enlargement of a streamlined landform, a crag-and-tail feature, exhibiting seabed pitted and ploughed by icebergs. (f) Enlargement of megaflutes, drumlins, and megagrooves on the southern flank of Grand Manan Basin. (g) 23-km long seismic reflection profile $\mathrm{y}-\mathrm{y}^{\prime}$ showing Grand Manan Basin glacial trough where erosion has truncated dipping reflectors (vertical black arrows) of pre-existing bedrock. IC1 and IC2 are ice-contact sediment; BR is bedrock. Acquisition system 6 cubic inch sleeve gun and 100 foot, single channel Teledyne hydrophone streamer. Frequency 200-750 Hz. VE x 24. Note: bathymetric colour scales in the images are different because they are determined by the water depth range depicted in each image.

Fig. 3. Seafloor bathymetric imagery and seismic reflection cross-sections showing glacial features on German Bank, Georges Bank, and in Northeast Channel. See Fig. 1a for locations of images. (a) Multibeam-bathymetric image of German Bank showing the pattern of recessional moraines (A, B, C) and De Geer moraines. (b) 16-km long seismic reflection profile $\mathrm{x}-\mathrm{x}^{\prime}$ normal to the strike of recessional moraines. PG is post-glacial sediment; IC is ice-contact sediment; GM is glacimarine sediment; Multiple is a second image of the seafloor, an artefact of the seismic reflection acquisition process. Acquisition system Huntec Deep-Tow Seismic. Frequency 0.5-8 kHz. VE x 47. (c) Multibeam-bathymetric image of Georges Bank showing modern sediment bedforms and the faint pattern of De Geer moraines. (d) Multibeam-bathymetric image of Northeast Channel and parts of Georges Bank and Browns Bank. Small De Geer moraines are faintly visible on Browns Bank. Dashed white line denotes the interpreted limit of incursion of icebergs from the Atlantic Ocean into Northeast Channel. (e) Multibeam-bathymetric detail of portion of 14-km long iceberg ploughmark in Northeast Channel showing well-defined berms. Other ploughmarks and keel grounding pits are visible. Note: bathymetric colour scales in the images are different because they are determined by the water depth range depicted in each image.

Fig. 4. Summary diagram (a) and schematic model (b) of the distribution pattern of submarine landforms in the Bay of Fundy-northern Gulf of Maine system. BoF is Bay of Fundy; GMB is Grand Manan Basin; GMBk is Grand Manan Banks; TS is Truxton Swell; CB is Crowell Basin; 
SR is Sewell Ridge; FM is Fundian Moraine; NEC is Northeast Channel; GB is German Bank. 

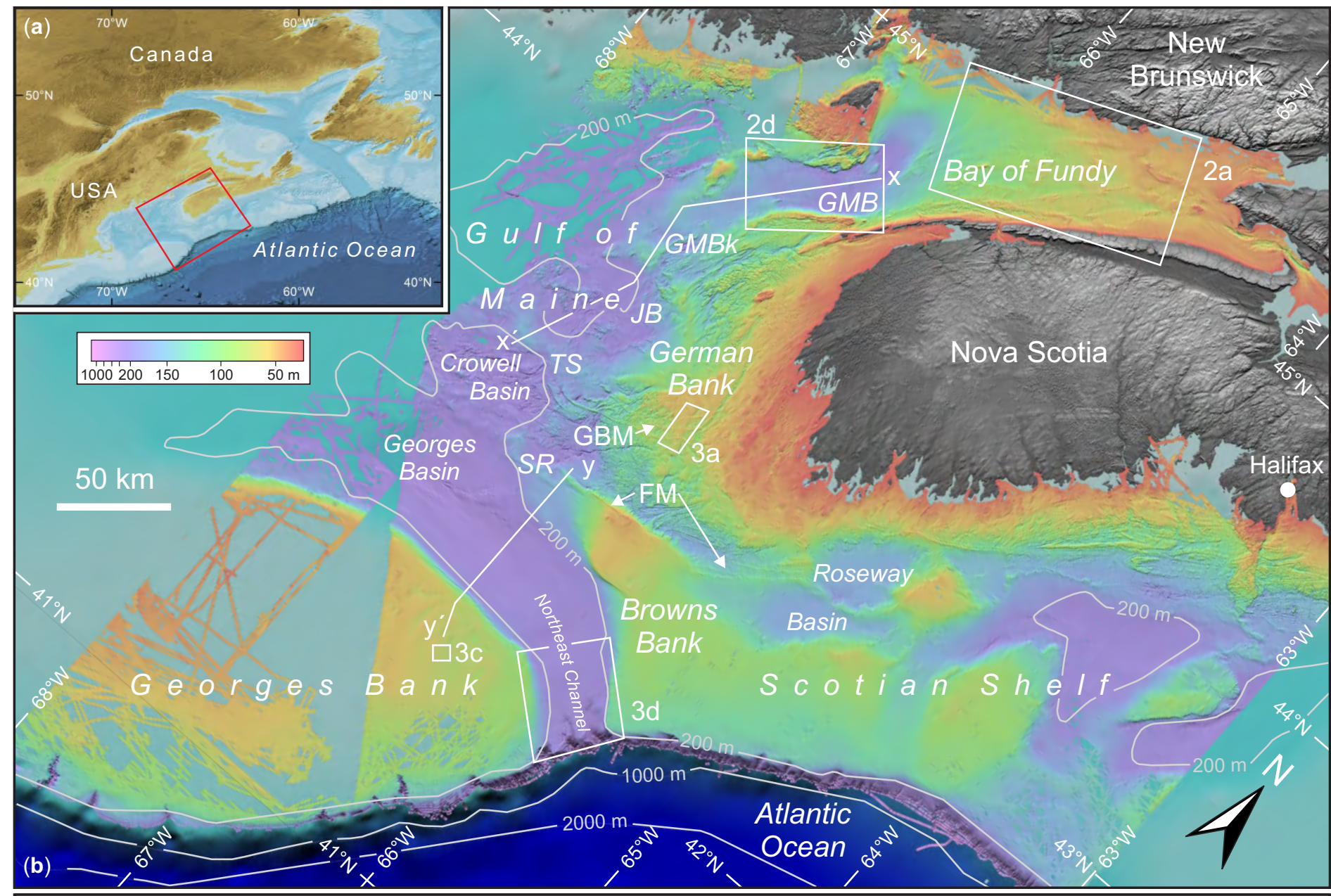

Basin
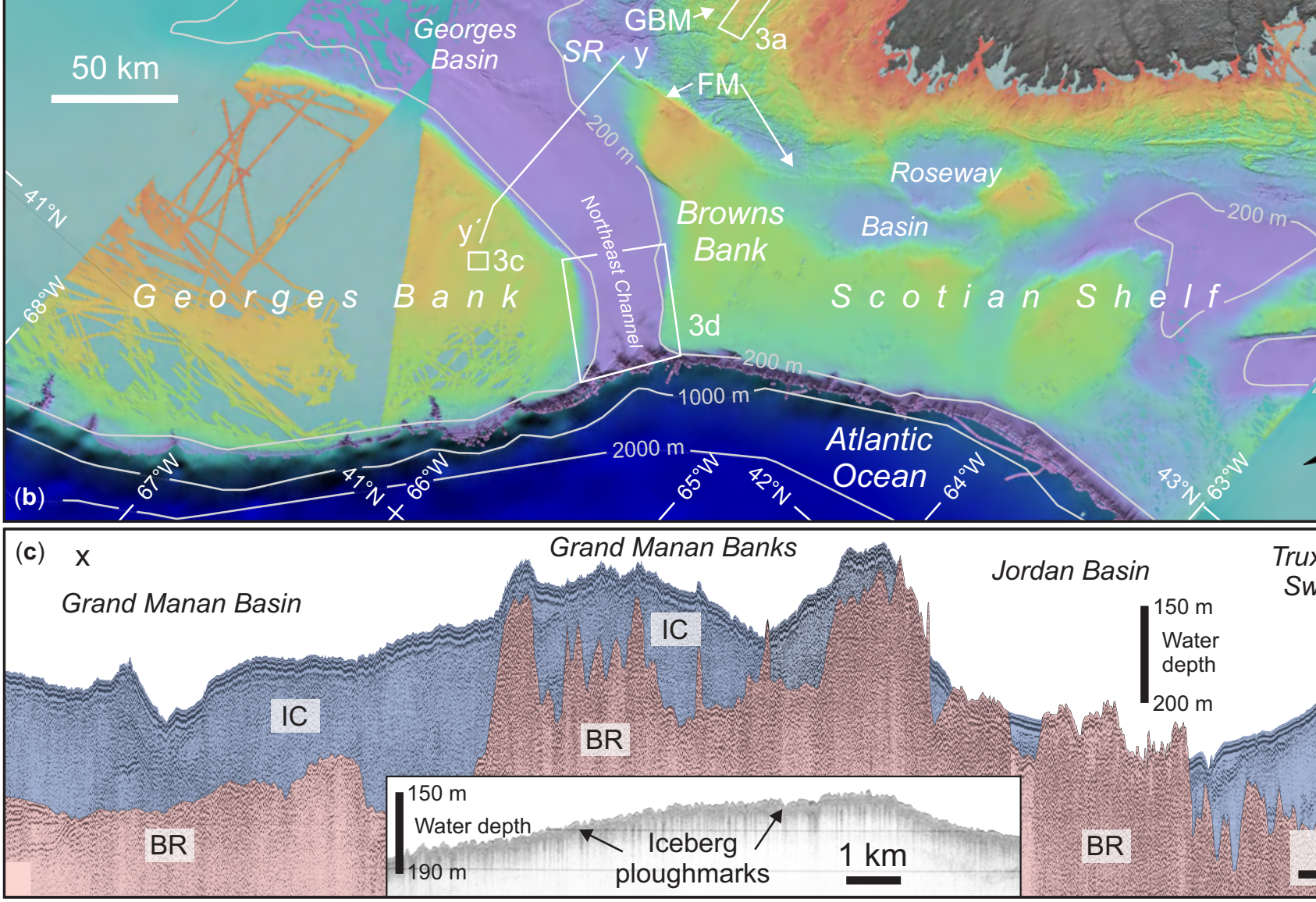

Roseway
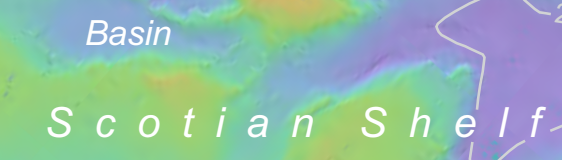

$n k$

\section{(d) y Sewell Ridge}

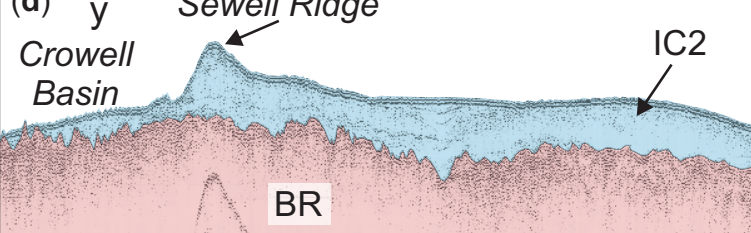

Water Iceberg ploughmarks

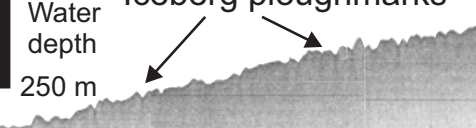

$250 \mathrm{~m}$

$1 \mathrm{~km}$
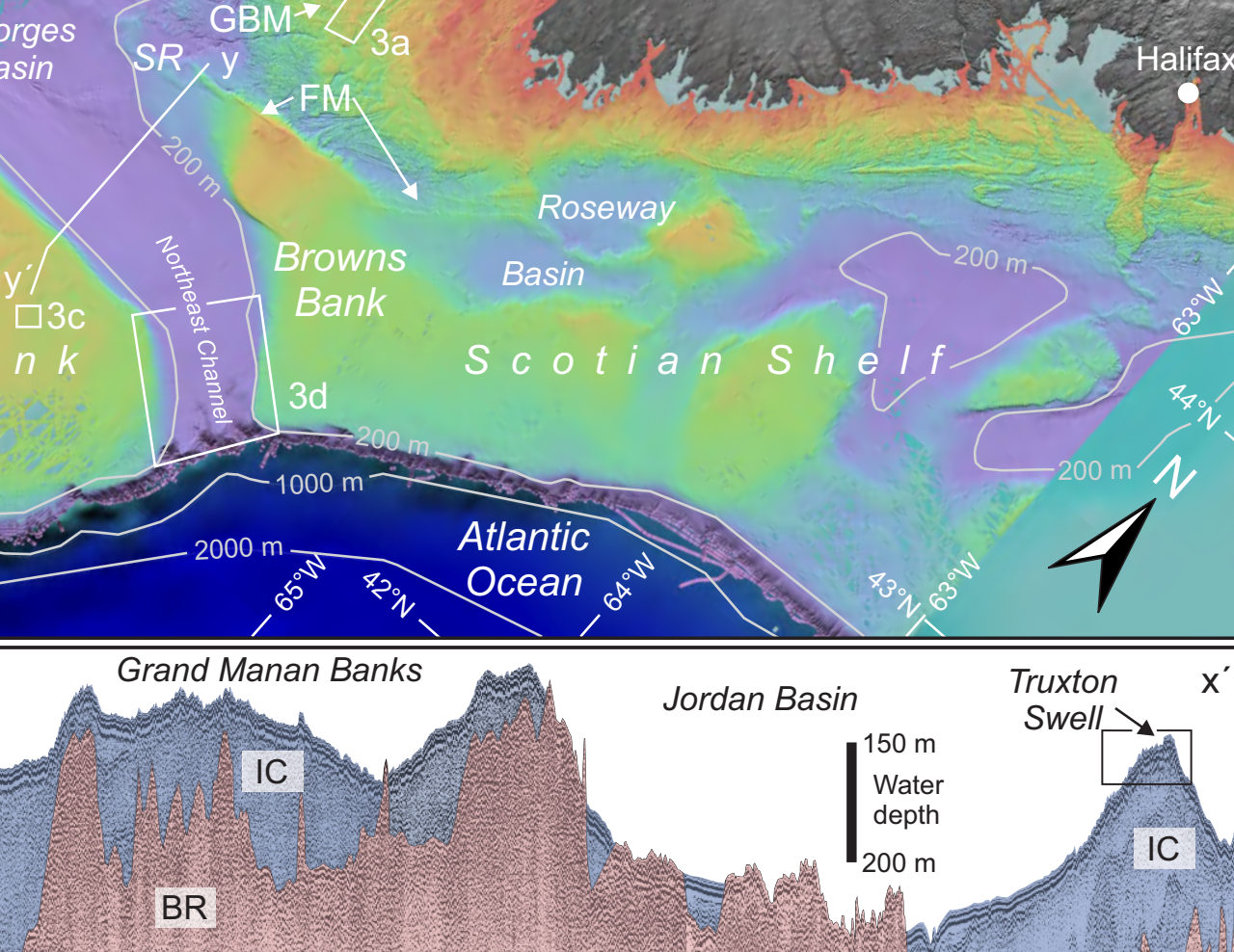



Figure 2 

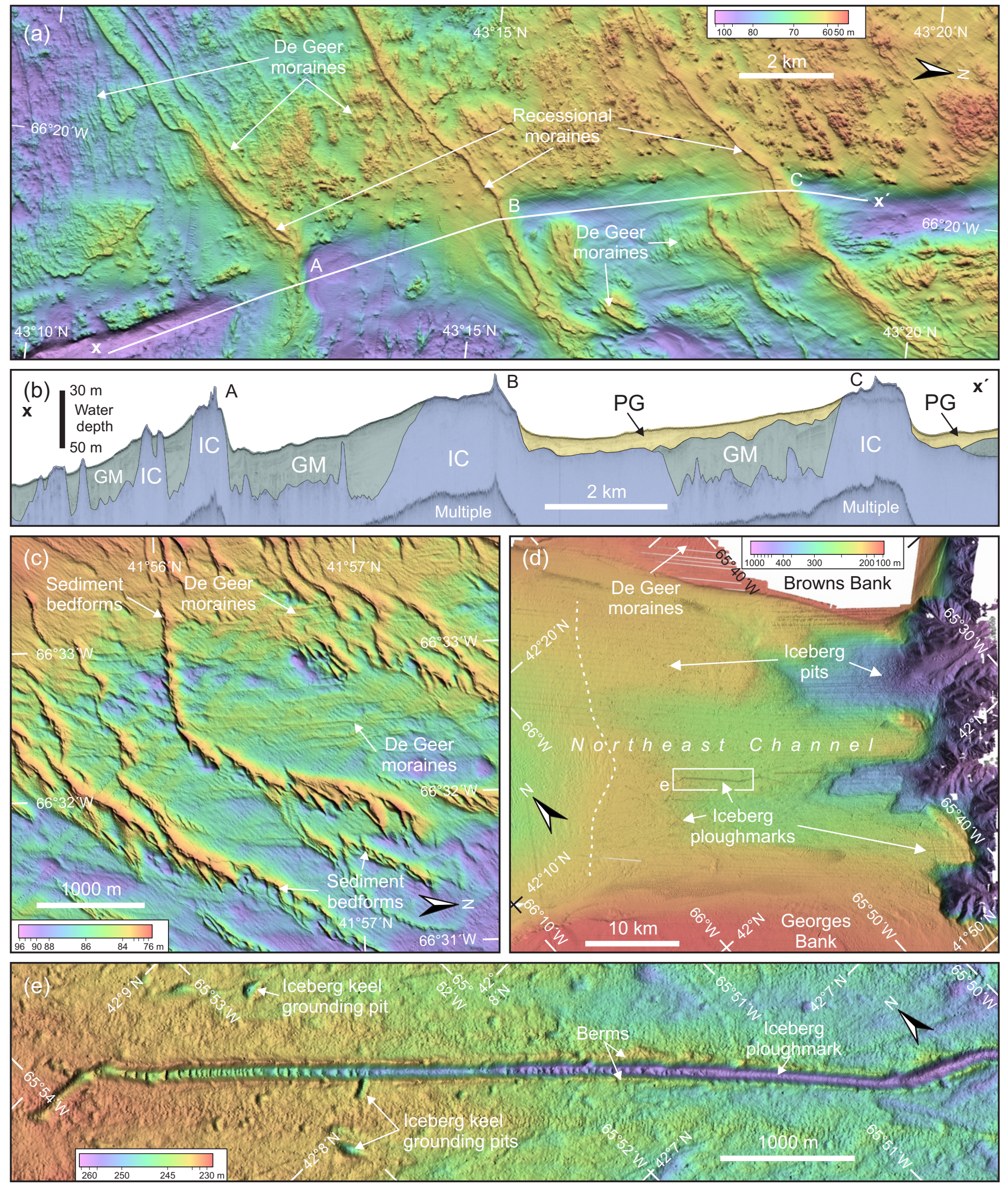

Figure 3 


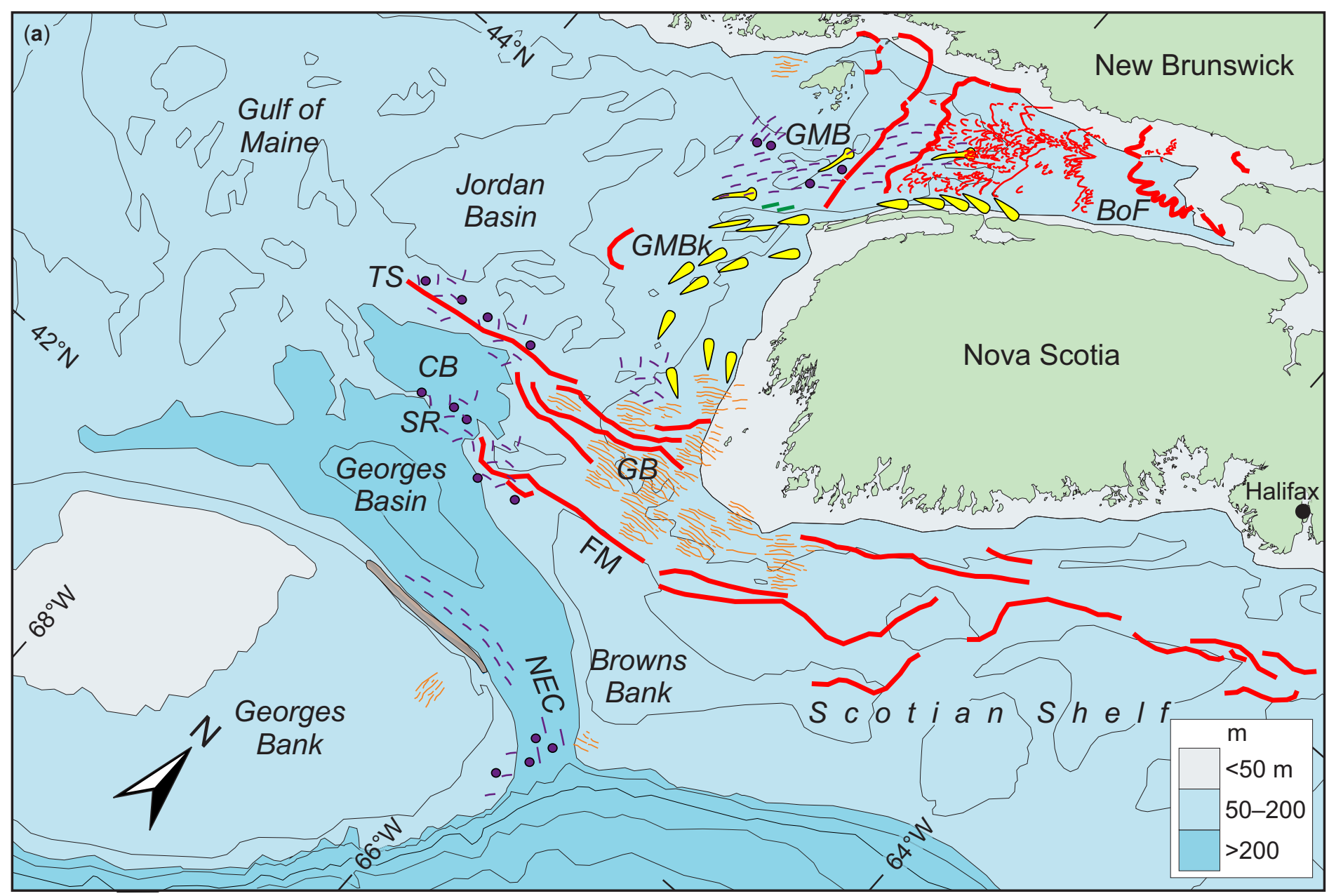

Legend:
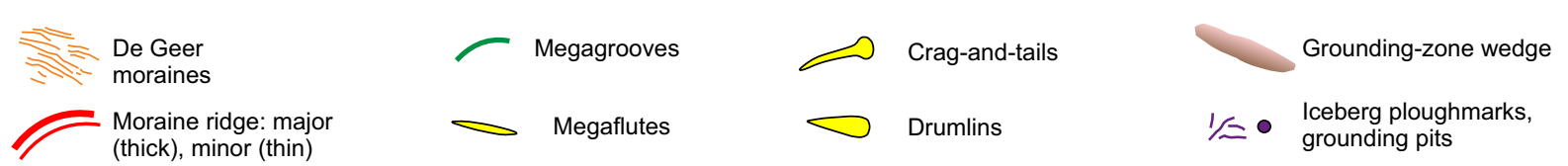

(b)

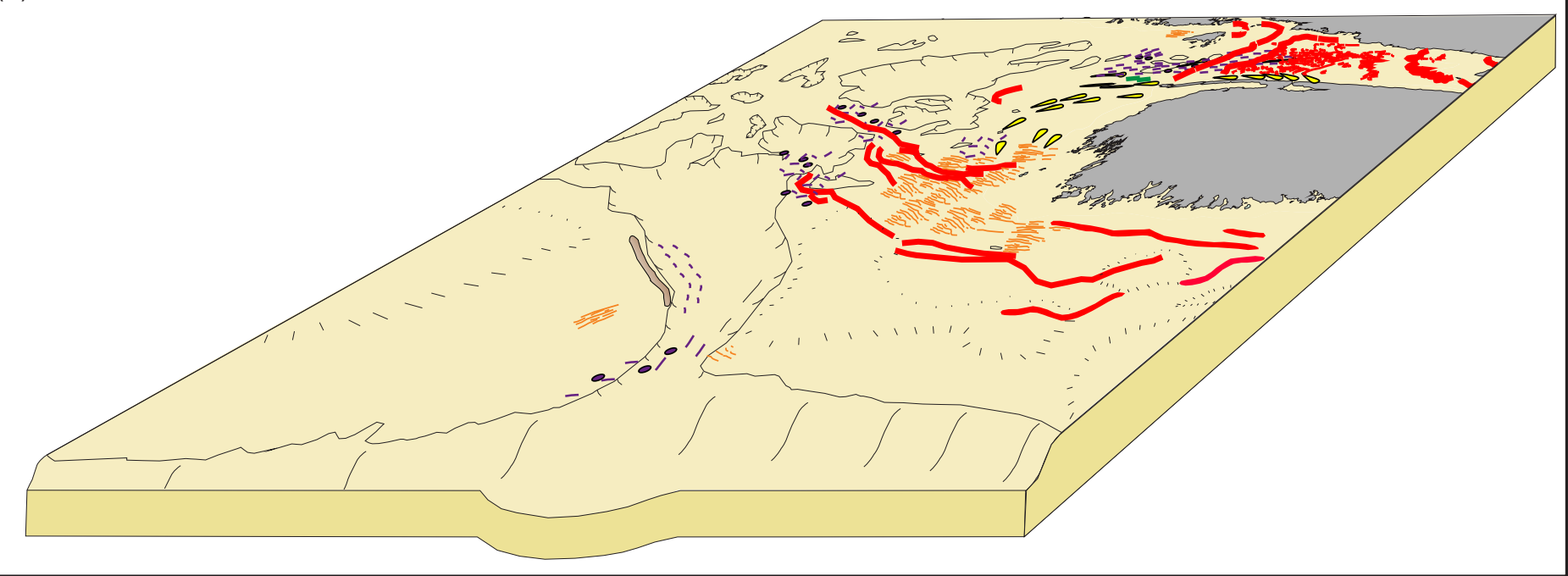

Figure 4 